\title{
CONTRACTUAL AGREEMENTS IN GHANA'S OIL AND GAS INDUSTRY: IN WHOSE INTEREST?
}

\author{
Kow Kwegya Amissah Abraham*
}

\begin{abstract}
This article examines the history, nature, scope and policy ramifications of the production sharing contract as the core contractual agreement guiding the Ghanaian petroleum sector. It discusses the policy linkages between this form of contractual agreement and the management of the country's oil exploration activities from 2010 to 2014. The article assesses the extent to which Ghana, as a new oil exporting country, has sought to actualize its resource benefits through negotiated contracts and agreements as well as management policies. The article argues that better negotiated contractual agreements ensure maximum State benefits from oil exploration. Again, production monitoring, periodic evaluation and institutional capacity building are effective ways of securing greater profits from oil resources. Finally, better legal and policy frameworks will also guarantee prudent management of the oil revenues.
\end{abstract}

Keywords: Contracts; policy-making; agreements; oil exploration and production; Ghana.

DOI: https://dx.doi.org/10.4314/jsdlp.v8i2.9

\section{INTRODUCTION}

As a natural resource, oil, even in its untapped and unexplored form, makes a country rich. But for its riches to translate to better human living conditions, it has to be exploited, produced and sold for the returns to be invested into the lives of the citizens of the country. ${ }^{1}$ The higher demand for capital, technological know-how, human resource

* BA, MPhil (Ghana), MPP (Germany), Lecturer, University of Cape Coast, Cape Coast, Ghana, and Executive Director, Centre for Policy Research and Training. kow.abraham@ucc.edu.gh

1 See Damilola Olawuyi, “The Increasing Relevance of Rights-Based Approaches to Resource Governance in Africa: Shifting from Regional Aspiration to Local Realization"(2015) 11(2), McGill International Journal Sustainable Development Law \& Policy, pp. 293, 319. 
and expertise in oil exploration have made it imperative for oil-rich countries to enter into contractual agreements with private transnational oil companies to explore such country's oil resources. This is, indeed, vital since it is the beginning of the extent to which a country will benefit or lose in the exploration of its oil.

Generally, a government has three main options for exploiting its natural resources. The first is to establish a state company with absolute authority over oil exploration and production, as is the case in Saudi Arabia, Oman, Iran, etc. ${ }^{2}$ The second is for the country to invite private companies to explore and produce, as is done in countries like Canada, the United States and the United Kingdom. The third option is to combine the expertise available in public and private companies to explore, develop and produce oil, as practised by states such as Azerbaijan, Nigeria, Kazakhstan, etc. ${ }^{3}$ From these options, government is expected to choose that which will enhance maximum benefit from its natural resources. Apart from the option whereby a government manages its own oil by taking absolute control of exploration and production, the other the options demand a contractual agreement between the government and the private oil corporations to determine their various interests and relationships. Even more, the onus of regulation is placed on the government since it has to monitor how these private companies comply with their mutual agreements.

If, for instance, a particular government opts to invite private oil companies into the industry, major contractual issues have to be raised and settled in the ensuing agreements. Two ready examples are how the cost of production is to be treated and how profits or rents are to be divided between the government and the oil companies. The enormous tasks involved in the oil business as well as the rigour of translating these into performance indicators in the contract agreements often reduce the government to an underdog in negotiation expertise. This is so because the vast resource base of transnational oil companies gives them the opportunity to hire top skilled professionals to negotiate for best deals. In this regard, developing countries are often disadvantaged. Again, the question of corruption plays an enormous role in the disadvantage. Most oil contracts and agreements are

2 Jenik Radon, "How to Negotiate an Oil Agreement", in M. Humphreys, J. D. Sachs \& J. E. Stiglitz (eds.), Escaping the Resource Curse (Columbia University Press, New York, 2007), pp. 89-113.

3 ibid. 
shrouded in secrecy, which makes it difficult to ascertain what actually transpires.

The aim of this article is to examine the form and scope of contractual agreements that Ghana entered into with the major oil companies operating within it as at 2013. The objective is to ascertain the extent to which these contracts benefit the country and potentially contribute to obtaining sustainable income to quicken economic growth. This position is motivated by the existing lacuna between resource abundance and development, which has been explained within the frameworks of the resource curse and paradox of the plenty theories. The major attributable reason for the translational problem of resource abundance and development has been corruption. This article, however, takes a different dimension by examining what actually goes into the contractual agreements and how the explorations are managed, using Ghana as a case study.

This article is divided into four sections. After this introduction, section 2 provides a detailed analysis of the contractual agreements that are open to oil producing countries and the history behind these agreements. The aim of the section is to explain why certain contractual agreements are prevalent in particular regions of the world as well as the factors that influence a country to adopt one contract instead of another. Section 3 concentrates on Ghana's contractual agreement. It assesses the two major oil companies in the country and the contents of the agreements they signed with the government. The objective is to provide a good background for understanding what Ghana is getting from its oil exploration. Section 4 is dedicated to examining the management and legislative frameworks that regulate the whole oil economy of Ghana. The aim is to assess possible missing links between policy design and implementation, which has been the problem with most developing oil-exporting economies. Section 5 is a reflective analysis and policy proposal of what ought to be done in future contractual agreements to ensure that Ghana gets maximum benefits from its oil wealth. The section also proposes solutions to strengthen the management frameworks to prevent occurrence of the resource curse phenomenon that has bedevilled other oil-producing countries.

\section{PETROLEUM CONTRACTS AND AGREEMENTS: ORIGINS AND EXPOSÉ}

Most African States take the option of entering into partnership 
agreement with private oil companies to explore their oil resources. Like other African states, Ghana has enormous economic problems, infrastructural deficits and other priorities which make it incapable of solely exploring its oil resources. ${ }^{4}$ Indeed since 1896, Ghana has employed the services of private transnational oil companies to explore the possibility of producing oil in commercial quantities. It seemsby default, therefore, that Ghana opted for an agreement which allowed it to collaborate with transnational oil companies. This also demands a contract negotiation and consequent signing with transnational oil companies. To be sure, the four main types of contractual systems in oil negotiation include Concession or License Agreement, Service Contract or Agreement, Joint Venture Agreement, and ProductionSharing Agreement. ${ }^{5}$ Thus, a country would have to first decide on the type of contract it wants before actual negotiation begins

Concession or License Agreement, the oldest and most widely practised contract system, has been in existence since the 19th century. It was developed in the 1800s when the United States began to explore oil. ${ }^{6}$ In the Concession Contract, a country grants exclusive rights to private oil companies to explore, produce as well as market its oil resources. ${ }^{7}$ This gives the oil companies exclusive rights over a long period of time. Giving such rights follows many processes such as competitive bidding, bonus signings, etc. It is important to note that the basic principle of this contract is anchored on the concept of land ownership in the United States. In that country, a landowner has absolute right over what is on, beneath and above the surface of the land. Thus, this agreement is seen more or less as granting a land ownership to a private company over a period of time for a fee and whatever the new owner finds beneath the surface of the land is considered as part of his property. This conception has gone through many modifications by other countries that have adopted it for use in

4 Morgan Bazilian, Ijeoma Onyeji, Peri-Khan Aqrawi, Benjamin K. Sovacool, Emmanuel Ofori, Daniel M.Kammen, and Thijs Van de Graaf, "Oil, Energy Poverty and Resource Dependence in West Africa" (2013), Journal of Energy \& Natural Resources Law, Vol. 1, No. 31, pp. 33-53.

5 Radon (n 2), pp. 89-113.

6 Tim Boykett, Marta Peirano, Simone Boria, Heather Kelley, Elisabeth Schimana, Andreas Dekrout, Rachel OReilly, Oil Contracts: How to Read and Understand Them (Austria: Times Up Press, 2012).

7 Michael Likosky,"Contracting and Regulatory Issues in the Oil and Gas and Metallic Minerals Industries" (2009) 18 (1) Transnational Corporations 1. 
the exploration of their oil resources. It explains why states such as Sudan, Angola, Ecuador and so on are able to use it. ${ }^{8}$

Again, this contract grants certain rights to the state to benefit from the initial concession payment, royalties and taxes from transnational oil company. However, the transnational oil company assumes all financial burdens in terms of exploration and production costs. Thus, the host government is exonerated from any financial burden and loss in the event that commercial reserves are not discovered during the period of exploration. The downside, however, is that governments and sometimes the oil companies themselves have no adequate knowledge of how much oil is there to be explored and so, most of the time, the agreement seems to be at the detriment of the government. Again, a company has the right to negotiate the price to bid for license. Since the transnational company determines the volume of production it is often realized that the government ends up losing. This happens especially when the compensation paid by companies are not tied to the value of the resources. ${ }^{9}$ It should also be noted that the contractual period given the company is normally a long lease. For instance, according to the oil concession of 1934, Kuwait granted a concession right to run for a period of 75 years. ${ }^{10}$

The second type of contract is the Joint Venture Agreement, which is not as popular as other agreements in oil exploration. In a joint venture agreement, the state works in partnership with the exploration companies. In that case, the exploration and production rights are awarded to the joint venture itself made up of the national oil company and the international oil companies. ${ }^{11}$ This agreement allows for substantial state participation even to the extent of sometimes holding the majority stake. ${ }^{12}$ It thus means that the role of a national oil company could be diverse. For instance, it could arrange credit facilities for loans to be granted in the international market; it could also be the regulating body or even hold the largest equity in the partnership. The agreement could also demand that the government get the required expertise and capacity to play a major role in the venture. Since parties ought to

8 Radon (n 2), pp. 89-113.

9 Likosky (n 7) 1.

10 Kirsten Bindemann, Production-Sharing Agreements: An Economic Analysis (Oxford: Oxford Institute for Energy Studies, 1999).

11 Boykett et al (n 6) 18.

12 Likosky (n 7) 1. 
agree on any venture, the agreement again demands that the parties understand themselves well. Parties also share risks in the venture and this makes the host government potentially responsible for resource extraction. Furthermore, this type of contract requires in-depth negotiation and extensive coordination between the contracting parties.

Furthermore, there is the Production-Sharing Agreement, which was introduced in Indonesia in 1966. The main motivation for this type of agreement is attributed to the legacy of colonialism. After independence, most colonized countries developed widespread resentment towards foreign control of their national resources. To curb this growing hostility and promote national interests, the Indonesian government reversed the already existing concessionary agreements which gave foreign companies absolute authority to explore, produce, manage and market its natural resources. To maximize its oil benefits, therefore, a new petroleum agreement had to be drawn up between the parties. Based on this agreement, the state, as the owner of the natural resource, i.e. oil, contracts foreign or transnational oil company to provide financial and technical services for the exploration and production of oil. ${ }^{13}$

In this agreement, therefore, the state remains the custodian of the oil resource and is represented by a national oil company. Through this, the government has the option to partake in the exploration and production in different forms. With this form of contract the transnational oil company bears the absolute burden of exploration risk. It receives no compensation whatsoever when there is no oil discovery in commercial quantities. Again, this approach provides a solution to the sovereignty issue since the resource is still owned by the state anyway. This agreement has four components: (i) The company pays royalty on gross production; (ii) It is entitled to a share for production cost recovery; (iii) The rent or profit is shared among the partners on agreed terms; and (iv) The company pays income tax on its rent. ${ }^{14}$ Generally, the agreement rests ownership of the resource in the state and then grants foreign companies the right to explore the oil. This benefits the state in the long run, especially as all financial risks are borne by the companies. However, governments' loss will be material ones given that the physical equipment for the production belongs to the state. ${ }^{15}$ Moreover, the downside of this agreement rests

13 Bindemann (n 10) 142.

14 Ibid.

15 Radon (n 2) 100. 
on the negotiating power between governments and its oil companies. This is so because much premium is placed on professional negotiation and government access to technical expertise.

Finally, there are Service Contracts, which have many similarities with the Production Sharing Agreement. A Service Contract involves a contractual agreement in which a government grants exploration and production of its oil to a foreign oil company for a pre-determined fee for a long-term period but remains the owner of the resource. ${ }^{16}$ The drift towards service contract can be explained by higher sovereignty concerns. ${ }^{17}$ The service contract differs from the production sharing agreement with respect to fees. Here, the international oil company agrees to a pre-determined fee in lieu of the profits to be earned. ${ }^{18}$ Although the service contract gives greater control of natural resource to the state, it has its own downsides. For example, it demands that states have strong institutions and monitoring framework. Also, they should have adequate expertise to better manage the resources. Thus the service contract places the onus of risk on the state since it has contracted only the services of a foreign oil company.

\section{AGREEMENTS AND CONTRACTS: GHANA'S OPTIONS}

Like many emerging oil exporters in Africa, Ghana opted for the Production Sharing Agreement in order to receive greater benefits from oil resource. To achieve this, the government operates through the Ghana National Petroleum Corporation (GNPC), its state oil company. ${ }^{19}$ Through GNPC, the government enters into petroleum agreements with the transnational oil companies. GNPC enters into negotiations with a Model Petroleum Agreement which spells out the basic terms of agreement. ${ }^{20}$ The agreed contract gives exclusive right to a foreign oil company to engage in petroleum operations in a given contract area.

16 Abbas Ghandi and Cynthia Lin C-Y, "Oil and Gas Service Contracts around the world: A Review" (2014) 3 Energy Strategy Reviews, pp. 63-71.

17 Tengku Machmud, The Indonesian Production Sharing Contract: An Investor's Perspective(Kluwer Law International 2000).

18 Ghandi and Lin (n 16), p. 65.

19 Ghana National Petroleum Corporation," History and Exploration in Ghana" (2014) < http://www.gnpcghana.com/overview.html> Accessed July 2014.

20 Ibid. 
According to the Model Petroleum Agreement Act (2000), the GNPC participates in the management of petroleum operations through the establishment of a Joint Management Committee with the foreign oil company. ${ }^{21}$ In accordance with the agreement, the state or its subsidiary, the GNPC, does not bear any financial risk in the event that oil is not found in commercial quantity during exploration. Thus, the foreign oil company absorbs the full cost of oil exploration. Additionally, the GNPC, under the agreement, is to hold a 10 per cent initial interest in all petroleum operations. ${ }^{22}$ This "carried interest" in oil exploration and development becomes a "paid interest" during production. The 10 per cent interest is subject to additional interest charges as determined by GNPC but this would have to be tabled within six months. The international oil company has to be reimbursed for all the expenditure attributed to the additional interest from the period of commercial discovery. ${ }^{23}$

This arrangement generally means that the contracting companies cannot hold an interest of more than 90 per cent in exploration and production operations. Concerning the period of exploration, it is not be more than seven years with a possibility of two extensions, for which the company has to apply in writing through the Minister of Energy. ${ }^{24}$ After signing the agreement, the oil company also has a maximum of 60 days to begin exploration. In the event of the discovery of oil in commercial quantity, Article 8.1 of the Agreement states that the contractor is supposed to notify, in writing, the Minister of Energy and the GNPC within 30 days. ${ }^{25}$ Again, Article 10 of the model agreement is dedicated to the sharing of crude oil that will be produced and further states that 12.5 per cent of the total production will be considered as royalty to the state as stipulated by the Petroleum Law. ${ }^{26}$ The state, in this case Ghana, reserves the right to receive this either in the form of crude oil or cash. The GNPC, which represents the state as the national oil company, collects all petroleum monies due to the state.

21 GNPC, Model Petroleum Agreement (2000) < http://www.eisourcebook.org/ $\mathrm{cms} /$ files/attachments/policy-legal-contractual-regulatory/Ghana\%20\%20Model\%20Petroleum\%20Agreement.pdf $>$ Accessed April 2014.

22 Ibid.

23 Ibid.

24 Ibid.

25 Ibid.

26 Ibid. 
The agreement further tasks the state and GNPC to supply crude oil for local consumption. This has to be supplied from the state's entitlements under the agreement. In the event that this is not enough for domestic consumption, the GNPC can purchase more crude from its partner, the oil company in charge of exploration and development, or other contractors to make up the shortfall. Article 16, on the other hand, mandates the contractor to keep the GNPC informed of all developments during exploration by sending periodic reports, data, samples, and so forth, and treating all such information as confidential. ${ }^{27}$ Furthermore, the GNPC is to have the inspection and monitoring rights to assess the offices, installations and structural facilities for audit in consultation with the contractor. This is to ensure that the contractor provides effective health and environmental safety systems, obeys labour laws and all other regulations stipulated in the agreement as well as the laws of the land. As the National Oil Company (NOC), the GNPC becomes the sole owner of petroleum produced and recovered except the state and contractor's entitlements. It is also the owner of the physical assets except those purchased and installed for use by the contractor for which the full cost has not been recovered. Article 20, stipulates that in the event of equipment purchase, the contractor is obliged to consider local preference which also includes the provision of services. ${ }^{28}$

The terms of the agreement did not leave out local contents in the industry. In addition to employment, the contractor is mandated to pay US $\$ 200,000$ per annum to GNPC for the training of Ghanaian personnel. ${ }^{29}$ This is to ensure effective technical and managerial skills transfer and efficient conduct of petroleum operations. The contractor is expected to consider this money as production cost. The contractor is also expected to submit an employment plan showing the number of persons and technical skills needed to GNPC and ensure that local citizens are given the jobs. A job window is also to be created for personnel nominated by GNPC to been rolled by the contractor either for internship or on-the-job training. These opportunities will include short, industry-related courses and continuing education, and the cost of such training is regarded as part of the production cost. The life span of the agreement is 30 years; however, there is the possibility of

27 Ibid.

28 Ibid.

29 Ibid. 
a contract renewal based on newly negotiated terms and agreements. ${ }^{30}$ The contract takes care of each contract area and the government is at liberty to enter into agreements with more than one oil company in a particular contract area. For instance, in the West Cape Three Points (WCTP) contract area, government signed a contract with Kosmos and E.O.Group. This sometimes makes negotiation complicated since each party has different vested interests and negotiating capacity. Government negotiates with these contractors as a joint operation group to make the process easier to deal with.

\subsection{Contractual Agreement: Deepwater Tano}

The Deepwater Tano (DT) block is one of the most important oil contract areas under current development and production. This is the area where most of Ghana's oil production comes from and it is also where the Jubilee field, the Tweneboa field, and other newly discovered fields are located. The contracting parties at Deepwater Tano are mostly Tullow Oil, Kosmos Energy Sabre Oil and Gasand Anadarko. The negotiated contract is a joint operating agreement between the various companies. With the Model Petroleum Agreement as the basic guideline the Deepwater Tano contract was not significantly different from the model agreement.

According to the Petroleum Agreement (Deepwater Tano, 2006), the exploration period in this contract area should not to be more than six and a half years (78 months) and it is to be divided into two periods. ${ }^{31}$ First is the two and a half years (30 months) of initial exploration period, which is further divided into one year and one and a half years (18 months) sub-periods; and the second period which is an extension period covering four years, split into two years each. ${ }^{32}$ Also, the GNPC makes all the documents and information concerning the contract area available to the contractor upon request and gets reimbursed for the cost of providing such information. For effective project execution, therefore, the contractor should target a minimum expenditure of US\$2 million during the first phase of exploration and

30 Ibid.

31 Petroleum Agreement-Deepwater Tano "Files" (2006) <https:// www.tullowoil.com/Media/docs/default-source/5_sustainability/petroleum_ agreement_deepwater_tano.pdf?sfvrsn=4> Accessed September 2017.

32 Ibid. 
US\$20 million during the second phase. ${ }^{33}$ Article 6 of the contract mandates the setting up of a Joint Management Committee to aid in the smooth operation of petroleum operations with membership of this management committee comprising four GNPC appointees and four appointees of the oil company with the chairperson chosen by GNPC. ${ }^{34}$ The management committee will meet at least twice a year with not less than 20 days' notice to members. The committee will also establish technical, accounting or auditing sub-committees and receive from the contractor an annual work programme and budget proposal on the planned activities for the year.

Furthermore, Article 7 of the contract gives absolute responsibility for the conduct of petroleum exploration to the contractor ${ }^{35}$ on the condition that full and accurate records are submitted to the government. In the event of the discovery of oil in commercial quantity, the oil minister is to be informed within 30 days. ${ }^{36}$ Following the discovery of oil, the contractor is required to prepare appraisals and development plans, including estimates of capital and operational expenditures, for the oil minister's approval. The GNPC can also arrange to appraise a discovery, but that is only when a contractor has not shown adequate interest in appraising the discovery. In that case, the GNPC will appraise the discovery on a sole cost basis and bear the risk of expenditure. Furthermore, Article 10 stipulates the sharing of crude oil among the parties and the entitlement of the state to a royalty of 5 percent of gross earnings from crude oil production as determined by the Petroleum Law. ${ }^{37}$

Again, crude oil with an API gravity of $18^{\circ}$ shall attract a royalty of 4 percent on gross production with the state being entitled to a gross production royalty of 3 per cent on natural gas. ${ }^{38}$ The state reserves the right to either receive the royalties in cash, based on the prevailing market price, or crude oil to meet its local consumption while the rest is sold off. After the deduction of the royalty, the rest of the crude is shared in accordance with the interest holdings between GNPC and

33 Ibid.

34 Ibid.

35 Ibid.

36 Ministry of Energy and Petroleum, "License" (2013)<http:// www.energymin.gov.gh/sites/default/files/ghana_model_petroleum_ agreement $\% 281 \% 29 . p d f$

37 Petroleum Agreement-Deepwater Tano (n 31).

38 Ibid. 
the contractors concerned. The agreement further instructs that all payments by the contractor to the state or GNPC, including income tax, should be made in American dollars; ditto for all payments from GNPC to the contractor - they must also be made in dollars and through electronic transfer. ${ }^{39}$ Then, again, the state and GNPC have responsibility for the domestic supply of crude oil. In the event that domestic supply is inadequate, the state will pay the contractor and give him a threemonth notice to provide additional volumes of crude.

\subsection{Contractual Agreement: West Cape Three Points (WCTP)}

The contract area during the agreement was operated by Kosmos Energy and the E.O. Group who have now sold their stake in the contract area to Tullow Oil. ${ }^{40}$ The agreement allows for an exploration period of seven years structured into three years initial exploration period with a subdivision of one and a half years each. Then there is the four years extension of two years each. ${ }^{41}$

Exploration is to begin within 75 days after the signing of the contract with a minimum budget of US\$4 million for the initial exploration period and US\$8million for the second sub-period. ${ }^{42}$ Any further extension will require a minimum of US $\$ 8$ million budget and a joint management committee made up of four members; two appointed by the GNPC and two by the contractor. ${ }^{43}$ Here, again, the committee will oversee petroleum operation in the contract area. Article 10 of the agreement indicates that the state will be entitled to a 7.5 per cent royalty on the gross production of oil, 5 per cent for crude oil with API of $20^{\circ}$ and another 5 per cent for gross natural gas production. ${ }^{44}$

This forms the bases of the contractual agreement at the two most important contract areas in Ghana's oil exploration. It should be realized that the model agreement reflects in the main agreements

39 Ibid.

40 Kosmos Energy, “Operations” (2012) < http://www.kosmosenergy.com/ operations-ghana.php $>$ accessed April 2014.

41 Petroleum Agreement - West Cape Three Points (2004) <https:// www.tullowoil.com/Media/docs/default-source/5_sustainability/ petroleum_agreement_west_cape_three_points.pdf?sfvrsn $=4>$ Accessed September 2017.

42 Ibid.

43 Ibid.

44 Ibid. 
examined. These agreements determine how much Ghana is getting from its oil exploration. Also important is the inclusion of local preferences in terms of human resource, services and equipment needed for exploration and production, even though Ghana does not have the industrial and manufacturing capacity to produce the equipment. The framework for the contract, the production sharing agreement, is expected to positively impact on the relationship between government, represented by the GNPC, and the international oil companies.

\subsection{Regulatory and Management Policy}

Readiness for oil exploration is not dependent only on infrastructure and capital availability. It also depends or existing legislations, laws and all regulatory instruments in the petroleum industry. The moment Ghana began oil exploration, it became necessary to pass many laws to monitor and regulate its oil exploration and production activities. The same development also necessitated the establishment of regulative and coordinating bodies in the oil sector. To effectively assess the extent to which Ghana has gone in getting the best out of its oil exploration, it is pertinent to examine the various legislative enactments and the veracity of these instruments.

Petroleum legislation in Ghana encompasses both the upstream and downstream sub-sectors of the industry. The downstream sub-sector, which entails importation, refining, storage, transporting, distributing and petroleum marketing, is dominated mainly by local companies. ${ }^{45}$ These companies concentrate mostly on the transportation and distribution of oil. There is also the retail aspect, which has maximum local content. Indeed, it is illegal for a non-Ghanaian to engage in retail business in Ghana. Therefore, the commercial aspect of Ghana's downstream industry is predominately controlled by local companies.

Ghana's economy is fully dependent on oil in terms of consumption. In fact, crude oil consumption represents almost 70 per cent of the energy needs in Ghana with consumption as at 2012 standing at approximately 950,000 tons per annum. ${ }^{46}$ Tema oil refinery, in its current capacity of 45,000 barrels, meets about 60 per cent of the domestic

45 Kimathi Kuenyehia Sr, Sefakor Kuenyehia and Augustine Kidisil, "Oil Regulation: Ghana”, in B. P. (ed.), Law Business Research (Encompass Print Solutions, London 2011).

46 Ibid. 
demand for oil. ${ }^{47}$ The refinery has been facing serious financial problems which have debarred it from reaching its refinery capacity for some time now. Again, government's commitment to increasing its refining capacity to about 100,000 barrels has not been realized. The entitlement of Ghana from the exploration is sold on the international market by Vitol SA, which also has the contract to market Tullow's share of the oil production from the Jubilee field and Cirrus Oil Services, a local company established in 2007 and licensed as a bulk oil distributor. ${ }^{48}$

Laws such as the Ghana National Petroleum Corporation Law, 1983, the National Petroleum Authority Act, 2005, and the Energy Commission Act 541, 1997, regulate the activities of Ghana's downstream industry. ${ }^{49}$ Act 541, which established the Energy Commission, gives it the task of regulating and managing energy and power (electricity) in Ghana. ${ }^{50}$ There is also room for advisory roles whereby the Ministry of Energy and Petroleum receives suggestions on how and what policies to make to achieve efficient and effective supply of electricity and petroleum. The statute also empowers the Energy Commission to grant licences to companies to transmit, make wholesale supply of, distribute, market and store petroleum products. ${ }^{51}$ Act 691, which established the National Petroleum Authority (NPA) bestows on it the responsibility of overall regulation and monitoring of the downstream petroleum industry. ${ }^{52}$ The NPA is also responsible for petroleum price adjustments and review.

In the upstream industry, there are regulations that govern the conduct of activities as far as oil exploration is concerned. The supreme law that primarily governs all contracts relating to natural resources, including oil, is the 1992 Constitution. In article 257 of the 1992

47 Ibid.

48 Petroleum Revenue Report, "Annual Report on Petroleum Funds" (2014) <http://www.mofep.gov.gh/sites/default/files/news/2014\%20Annual\% 20Report\%20on\%20the\%20Petroleum\%20Funds.pdf> Accessed September 2017.

49 Robert Adjaye, “Ghana's Oil Find: Technological Challenges for Upstream Skills Development"(Accra 2009).

50 Energy Commission Act , 1997 (Act 541) <http://www.energycom.gov.gh/ files/ACT.pdf $>$ Accessed April 2014.

51 Kimathi Kuenyehia Sr, Sefakor Kuenyehia and Augustine Kidisil (n 45), p. 79.

52 National Petroleum Authority Act , 2005.<http://www.eisourcebook.org/cms/ February\%202016/Ghana\%20National\%20Petroleum\%20Authority\%20 Act\%202005.pdf> Accessed September 2017. 
Constitution of Ghana, every mineral beneath the surface of the land demarcated within the territorial borders of Ghana, including the continental shelf, belongs to the state and is vested in the President on behalf of the people of Ghana. ${ }^{53}$ This constitutional provision makes it clear that individuals may own lands in their private capacities provided no natural resource such as metallic resource or extractive resource can be found underneath them. All minerals found under such privately held lands automatically revert to the President who exercises authority over such resources on behalf of the people of Ghana.

This constitutional provision differs significantly from the basic idea that underlies the concession agreement of the 1900s in which landownership by private individuals included any resource beneath or above the surface of the land. In this vein, it is the government who can grant the right to explore any mineral in accordance with due process. The Constitution again stipulates that any right given to foreign companies to explore natural resource in Ghana requires a parliamentary ratification. ${ }^{54}$ This means that the President or any member of government cannot unilaterally give concession right to anyone to exploit mineral resources without the approval of the Parliament. This provision is meant to serve as a check and balance on the authority of the Executive and thus prevent possible abuse of authority or privilege either by the President or his appointees.

Again, there are other statutes that are used to regulate the upstream industry. These are the Petroleum Revenue Management Act, 2011, the Petroleum Income Tax Law (PNDCL 188), 1987, the Petroleum Exploration and Production Law (PNDCL 84), 1984, and the Ghana National Petroleum Corporation Law (PNDCL 64), 1983. These laws form the bases of the upstream legal framework in the regulation and the conduct of petroleum operations. The Petroleum Exploration and Production Act of 1984 reemphasises the ownership of petroleum resources as a state asset and as a result creates the contractual relationship that ought to take place between the state, represented by GNPC and the transnational oil companies. ${ }^{55}$ The Law also takes care of government entitlements in terms of royalties and

53 The 1992 Constitution of Ghana.

54 Ibid.

55 Petroleum Exploration and Production Act, 1984. < http://www.energymin.gov. $\mathrm{gh} /$ sites/default/files/petroleum_exploration_and_production-law_1984 _pndc_law_84.pdf> Accessed September 2017. 
interests and also prescribed income tax system in the petroleum operation.

The Ghana National Petroleum Corporation Law (PNDC 64), 1983, is also the law that establishes the Ghana National Petroleum Corporation (GNPC). ${ }^{56}$ The GNPC is generally in charge of exploration, development and production of oil. Since its establishment, it has collaborated with many international companies on oil exploration activities. It should be noted also that as, the national oil company, GNPC manages the state's interest in the exploration and production of oil. The Petroleum Income Tax Act, 1984, sets out the law governing the tax system in the upstream petroleum industry. ${ }^{57}$ Through this law, the incomes to be taxed and the percentage of taxation are all spelt out. Hence, this law regulates the tax monitoring aspect of oil exploration and production. There is also the Petroleum Revenue Management Act, 2011, which provides the framework for how petroleum revenue will be used. ${ }^{58}$ Reflectively, the regulatory framework goes a long way in ensuring efficiency in the management of oil exploration in Ghana. The problem, however, is the extent of its applicability. To be sure that these regulations are complied with, there are monitoring mechanisms and established bodies mandated to enforce due compliance. Thus, there also are monitoring bodies put in place to manage the exploration and production industry.

Extractive activities have been seen to adversely affect the local communities where the exploration is done. Thus exploration has associated institutional, financial, health, environmental and political impacts that could be detrimental to growth. There are examples of many resource-rich countries that mortgaged their sustainable development mainly because they negotiated a bad deal in the exploration of their natural resources. Even more relatable is the virtual non-existence of effective regulatory frameworks and efficient management strategies to better govern the exploration operations.

Effective management of petroleum resources is daunting and requires a lot of factors and ground rules. This explains why most oilexporting countries in Africa seem susceptible to policy failure. Since oil exploration is capital intensive and technology driven, it has always demanded extensive skill, knowledge and the technological

56 Ghana National Petroleum Corporation Act.

57 Petroleum Income Tax Law 1987.

58 Petroleum Revenue Management Act. 
advancement to execute. Therefore, states that wish to explore their oil resources must be adequately prepared in terms of capital and the technological know-how. Again, oil resource exploration demands cruise interplay between economics and politics. The successes and failures of fully maximizing the rents accruing from mineral exploration are more political than economic. This begins with the negotiated agreements and contracts. Many oil rich countries in Africa go through various difficult times during the oil negotiation stage. Anecdotal evidence shows that it is, indeed, a period of underground activities such as corruption, patronage and kick-backs. However, because these are done under the table, it is difficult to determine their prevalence beyond reliance on perception based methods.

\section{POLICY DIRECTION AND RECOMMENDATIONS}

Much premium has always been placed on how resource-rich countries that are experiencing stagnant growth have failed to make use of their accrued revenues for accelerated development. Many reasons have been adduced for this phenomenon, such as corruption, whereby realized revenues do not reach the public purse. Others include lack of proper prioritizing by these governments and excessive spending. The real causes for the so-called resource curse are, however, composite; even more contributory is the existing non-transparency and inequity in the negotiating and signing of contract agreements between states and transnational oil companies. Many agreements entered into with transnational oil companies for exploration, development and production rights seem to be terrible agreements, with the State always being at the losing end. For instance, the Zambian government negotiated for a royalty of 0.61 per cent in the mining of its copper at the Konkola Mines out of a total income of US\$1 billion. ${ }^{59}$ Thus, negotiated agreements play an enormous role in the management of natural resources. This is not to say that a country ought to surcharge in the exploration operation, but that there has to be equitable percentage negotiations.

Ghana has been mining gold for over 40 years and has continued to receive a royalty of 3 per cent on until 2011 when it was increased

59 Oxfam International, "Lifting the resource curse" (2009) www.oxfam.org: http:/ /www.oxfam.org/sites/www.oxfam.org/files/bp134-lifting-the-resource-curse011209.pdf. Accessed April 2014. 
to5 per cent after many years of failed attempts to review it. ${ }^{60}$ In the case of oil exploration Ghana's negotiations has been guided by the model agreement, which spells out the various percentages due the State. For instance, the agreement stipulates a threshold of $12^{1 / 2}$ per cent of royalty. However, in the Deepwater Tano agreement where Jubilee field is located, Ghana was able to negotiate up to 5 per cent of royalty. This was less compared to West Cape Three Points contract area where it negotiated $7^{1 / 2}$ per cent of royalty.

It is important to note that royalty and carried interest account for a greater part of accrued revenue to the State. Therefore, if a country fails to negotiate well, it will inevitably suffer revenue inadequacy despite nature's generosity to it. As a common practice, negotiating countries are made to understand that profit increases for both the government and the transnational oil companies when royalties are low. The argument thus advanced is that since government will ultimately collect rent and corporate tax it would fill the royalty gap. Experience has shown that this is not necessarily the case, especially when government cannot rely on transnational oil companies to always pay their taxes. For instance, in the 2011 and 2012 financial years, oil companies did not pay their corporate tax, and this affected the budgeted income of government with a negative variance of US $\$ 232.10$ million in 2012 alone. ${ }^{61}$ Thus it is always necessary for the government to sharpen its negotiating skills and aim for the best deal possible.

Moreover, it should be noted that the transnational oil companies are big industry players that are sometimes bigger than some of the countries they negotiate with in terms of capital. It thus places them at an advantage on the negotiation table. This is because they can afford the best skilled negotiators and technocrats in order to have the best deal. In Ghana, the policy of winner-takes-all in elections where the party that wins elections absolutely forms government and controls everything without any opposition involvement has made every issue be deeply politicized. Thus, appointments into critical areas of governance and the economy, including the Chief Director of the National Oil Company, GNPC, are reserved for political associates instead of qualified and experienced technocrats. This gives the room

60 KPMG, "Ghana: Country Mining Guide"(2014).<https://assets.kpmg.com/ content/dam/kpmg/pdf/2014/04/ghana-mining-guide.pdf $>$ Accessed September 2017.

61 Petroleum Revenue Report (n 48). 
for patronage, favouritism and nepotism. Given this scenario, it is difficult for a Minister of Energy and Petroleum who is inexperienced in energy and petroleum matters to fully engage in any technocratic negotiations that will lead to a good deal for the country. Of course, these appointees have experienced technocrats working with them in various supportive capacities but as long as the final decision lies in the hands of political appointees who are not merit-driven, experienced or patriotic, negotiating for a great deal would easily be thwarted.

\subsection{Management and Regulation: Policy Analysis}

The existing relationships between States and transnational oil corporations have always been murky, and this makes it difficult for policy analysts and scholars to propose better alternatives to improve their relationships. This is so because petroleum operations are always interwoven with the political order of the State. This is not to say that there are transnational oil companies doing politics in these States. Rather, since it is the political authority that can give rights to explore and it is the transnational oil companies that can explore and produce to improve the revenue profile of the country, their relationship becomes a bit more complicated.

Political regimes will always want to be in power even though the mechanisms they employ to hold onto power differs - ranging from legitimate elections to high handedness. If it is through legitimate elections, it means that they will always need additional revenues to increase spending and expand public projects to maintain their hold on political power. If it is through high handedness, they will still need additional income to consolidate their hold to power through patronage and clientilism. Transnational oil companies are also a business and, thus, for profit. This means that they look for avenues to increase their profit margins. Since oil exploration is a capital-intensive venture, transnational companies are always willing to invest in a country that gives them less investment risk, and a reliable political regime that will relax rules that can potentially strangulate investment opportunities. Again, because these companies compete with other transnational companies, they are always willing to offer the best deals to governments, sometimes through the back door, for exploration and production rights. This makes their partnership with governments something of a mutual interest.

Opting for petroleum-sharing agreement calls for improved relationship between the government and the oil companies. However, 
unlike a joint venture where every decision has to be taken on the basis of a compromise, existing relationship is more of regulatory than partnership it is always difficult to ascertain the nature of a previous relationship between a government and a foreign company prior to commercial production. This confirmation would have been vital to any reasonable assessmentin case any patronage took place that might have affected the terms of the signed contracts. In Ghana, an evidence of a prior relationship only came to light when Kosmos Energy, a United States company, was accused by Anadarko, another United States company, of bribing government officials to secure contracts. ${ }^{62}$ We note that government's relationship with transnational companies is vital as far as contract negotiation and petroleum production is concerned.

Since pre-existing relationships which normally affect contracts have enabling circumstances for secrecy, we dwell on existing relationships in the production period. As earlier described, the existing relationship between the State, that is Ghana, and the transnational oil companies is more regulatory and managerial. Regarding the production-sharing agreement, Ghana still exercises sovereign rights over its resources; hence it has the responsibility to ensure that petroleum operation is done within the stipulated laws and regulations. ${ }^{63}$ In this regard, there have been many regulatory frameworks to guide the petroleum operations. There are also established bodies to ensure that these regulations are complied with. Thus, as far as the various instruments are concerned, exploration operations are duly regulated. The problem, however, is that the institutions tasked with ensuring compliance are not always as efficient as people assume. For instance, the adverse effect of gold mining on the environment, especially on water bodies, farm lands, etc., as a result of the surface mining which has taken away the subsistence livelihood of the mining communities and the inadequate response from the Environmental Protection Agency is an evidence of how weak some of these institutions have been. Given that petroleum operations are currently offshore, the Agency does not have the required human and structural capacity to effectively ensure

62 David Wethe and Jason McLure, "U.S. Closes Inquiry as Ghana Probes Alleged Bribery at Jubilee"Bloomberg (2 September 2010) < http://www.bloomberg.com/ news/articles/2010-09-02/u-s-closes-inquiry-as-ghana-probes-alleged-briberyat-jubilee-oil-field $>$

63 Ransford Gyampo, "Saving Ghana from its Oil: A Critical Assessment of Preparations so Far Made" (2010) 3 African Research Review 4. 
compliance with international and national environmental laws.

Also, institutions established to check transnational companies' respect for labour laws in terms of salaries and conditions of service are not sufficiently proactive. Take example of the newly established Petroleum Commission. This is an institution that seems ill equipped with human and funding capabilities to adequately regulate and oversee the general health of the petroleum industry. The legislative arm of government appears even worse. The Parliament is so polarized that every issue, including developmental issues and regulatory duties, are politicized between the majority and minority divide. Consensus is mostly reached only on issues that affect the Parliament itself; the rest are subjected to hard party-line debates where the majority always have their way, and the minority, their say. This has greatly affected monitoring agencies.

The second dimension of the existing relationship is management of the country's petroleum industry. The petroleum contracts provide for the compulsory establishment of a Joint Management Committee. This Committee is made up of representatives of GNPC and the transnational oil companies in the contracting area. The Committee manages all operations of the fields, including annual budget approvals, equipment assessments and purchases, etc. ${ }^{64}$ Thus, the core administrative duties concerning oil operations are vested in the hands of the Committee. The establishment of the Committee is a laudable idea in that it further forges a close and cordial relationship between the contractors and the state. Since the State picks the chairman of the Committee, it exercises a great deal of control over the operations of the oil industry as a whole.

To date, there is no evidence that the Committee has become dysfunctional, which in itself is a good omen. Also, since GNPC receives 40 per cent of the State's carried interest, ${ }^{65}$ it is expected to use the funds judiciously, including money allocated for capacity building. There may be need to look more closely into how the committee uses money allocated for capacity building. This is in view of a report submitted by Public Interest Accountability Committee in 2012 which indicated that

64 Petroleum Exploration and Production Act.

65 Petroleum Revenue Report, "Annual Report on Petroleum Funds 2012"(2013) <https://s3.amazonaws.com/ndpc-static/pubication/2012+Annual+Report +on + the + Petroleum +Funds.pdf > Accessed September 2017. 
government through the GNPC ought to account for how money allocated for capacity building has been used. ${ }^{66}$ This implies that the GNPC itself should be well regulated and managed to ensure efficient and judicious use of its funds.

\subsection{Policy Summary}

Central to policy assessment is the provision of alternative or strengthening options for policy makers. It is obvious that strong institutions, better regulatory and legal framework and the needed political will are central to enhancing increased benefit from oil production and governance. To this end, the Ghanaian government must strengthen its negotiating capabilities. In other words, the government should appoint more technocrats and experienced people to key positions in the oil industry without recourse to political affiliation.

Also, there is a need to increase the State's interest from 10 per cent to a maximum 20 per cent. This will enable the State to better make use of its local content policy especially when oil production does not involve large employment base. Furthermore, it is also imperative to strengthen the various regulatory institutions like the Petroleum Commission, the Environmental Protection Agency, the National Petroleum Authority, and so on, to enable them regulate the petroleum industry better. Moreover, there should be enhanced capacity development at the GNPC. The Ghanaian government will need to equip GNPC to better manage the State's stake in the exploration operation. Again there is the need to delink the political appointment of the head of GNPC and make it a technocratic position.

Finally, there is a need to for the government to implement transparency measures by further strengthening Ghana's version of Extractive Industries Transparency Initiative. This will include removing information confidentiality clauses from contracts to make information on petroleum operations and licenses accessible and available for public consumption. Where the need to protect sensitive and classified public security information does not arise, general information on licensing, petroleum operations and the scope of work under existing contracts must be proactively disclosed to the public to promote a culture of openness in the petroleum sector.

66 Petroleum Revenue Report (n 48). 


\section{CONCLUSION}

Ghana's contracts are not necessarily a bad deal although the State could have done better given that we cannot always rely on the transnational oil companies to pay their taxes. Again, holding only a 10 per cent participating and carried interest is inadequate. This is because government itself must commit some capital to exploration with the accompanying risks. However, if the government was looking forward to good profits, then it could increase its interest in the stake to 20 per cent to increase its accumulated profits. This would have been necessary especially since government seeks to implement 90 per cent local content in the industry by 2020. It is difficult to imagine how government can implement such huge local content in a contract that has a life span of 30 years when it has only a 10 per cent interest in the stake.

One could argue that government does not need to commit capital to the exploration, but the government has given sovereign guarantees to private and foreign companies who have won contracts to undertake projects in Ghana, and so government could do the same thing when it comes to exploration. Indeed this goes with risks but there is the option of also engaging in prudent spending and prioritizing capital for that venture.

Production-sharing agreement does not prevent a country from having a maximum share of 20 per cent in the exploration of its natural resources. Indeed, this article proposes that government should take this into consideration in other contracts especially when it comes to royalty negotiation and carried interests. This is so because the current contracts are only subject to re-negotiations after 30 years. Thus, for the State to take charge of its natural resources proactively and make use of skills transfer, it is also must have an appreciable stake in the operations. This is the reason to depoliticize certain positions of employment especially in the GNPC and other relevant state institutions such as the Petroleum Commission. When that is done, a change of government will not necessarily warrant a new appointment, and that will lead to continuity, efficiency and impartiality. Again, those who occupy such position will feel more responsible to the State rather than the government, President and the political party in power, as is the case currently. 